\title{
Determinasi Hasil Belajar Matematika ditinjau dari Fasilitas dan Motivasi Belajar Siswa Kelas VIII SMP Muhammadiyah Palangka Raya
}

\section{Determination of Mathematics Learning Outcomes in terms of Facilities and Learning Motivation of Class VIII SMP Muhammadiyah Palangka Raya}

\section{Sugiharto' \\ Karlinah Salamanya ${ }^{2}$ \\ Walter Punding ${ }^{3}$ Yupito $^{4}$}

ISugiharto Program Studi Pendidikan Matematika Jurusan PMIPA FKIP UPR.

2Karlinah Salamanya Program Studi Pendidikan Matematika Jurusan PMIPA FKIP UPR.

3Walter Punding Program Studi Pendidikan Matematika Jurusan PMIPA FKIP UPR.

4Yupito Program Studi Pendidikan Matematika Jurusan PMIPA FKIP UPR.

email: mitaadnyani8I@gmail.com

agungmaheswari@undiknas.ac.id

\section{Kata Kunci:}

Determinasi,

Hasil Belajar Matematika,

Fasilitas,

Motivasi Belajar

Keywords:

Determination,

Mathematics Learning Outcomes,

Facility,

Motivation To Learn

\begin{abstract}
Abstrak
Penelitian ini bertujuan untuk mengetahui Diterminasi Hasil Belajar Matematika Siswa Kelas VIII SMP Muhammadiyah Palangka Raya ditinjau dari Fasilitas dan Motivasi Belajar. Populasi dalam penelitian ini adalah seluruh siswa Kelas VIII SMP Muhammadiyah Palangka Raya tahun ajaran 202I/2022 sebanyak 16I siswa. Sampel diambil sebanyak II9 siswa. Data fasilitas dan motivasi belajar siswa diambil dengan angket, sedangkan data hasil belajar matematika siswa digunakan tes. Pengumpulan data dilakukan secara online, dengan media Google Form. Untuk menguji validitas angket digunakan rumus korelasi Product Moment. Untuk menguji validitas tes, digunakan Indeks Kesukaran (IK) dan Daya Pembeda (D). Untuk memperoleh reliabilitas angket, digunakan rumus Alpha, untuk reliabilitas tes digunakan rumus KR-20. Data dianalisis dengan korelasi Product Moment, Korelasi Ganda, serta rumus Koefisien Determinasi. Hasil penelitian menunjukkan bahwa Ada hubungan positif yang signifikan fasilitas dengan hasil belajar matematika siswa, dengan nilai rhitung sebesar 0,33 . Ada hubungan positif yang signifikan motivasi belajar dengan hasil belajar matematika siswa, dengan nilai rhitung sebesar 0,43. Ada hubungan positif yang signifikan fasilitas dan motivasi belajar dengan hasil belajar matematika siswa, dengan nilai $R$ sebesar 0,43 . Sedangkan rtabel $=0,18$, Koefisien determinasi sebesar 0,18 .
\end{abstract}

\begin{abstract}
This study aims to determine the termination of Mathematics Learning Outcomes for Class VIII SMP Muhammadiyah Palangka Raya in terms of Facilities and Learning Motivation. The population in this study were all students of Class VIII SMP Muhammadiyah Palangka Raya in the academic year $2021 / 2022$ as many as 161 students. Samples were taken as many as 119 students. Data on facilities and students' learning motivation were taken using a questionnaire, while the data on students' mathematics learning outcomes was used as a test. Data collection is done online, using Google Form media. To test the validity of the questionnaire, the Product Moment correlation formula was used. To test the validity of the test, the Difficulty Index (IK) and Distinctive Power (D) were used. To obtain the reliability of the questionnaire, the Alpha formula was used, for the reliability of the test the KR-20 formula was used. Data were analyzed by Product Moment correlation, Multiple Correlation, and the Coefficient of Determination formula. The results showed that there was a significant positive relationship between facilities and students' mathematics learning outcomes, with an rcount of 0.33 . There is a significant positive relationship between learning motivation and students' mathematics learning outcomes, with an rcount of 0.43 . There is a significant positive relationship between learning facilities and motivation with students' mathematics learning outcomes, with an $R$ value of 0.43 . While rtable $=0.18$, the coefficient of determination is 0.18 .
\end{abstract}


Matematika mengajarkan sikap tekun dan pantang menyerah/gigih dalam menyelesaikan masalah. Siswa yang memiliki kemampuan memecahkan masalah matematika lebih mampu dalam memecahkan masalah dikehidupan sehari-hari (Mairing, 20l8). Oleh karena itu, wajar bila mata pelajaran matematika merupakan salah satu mata pelajaran yang diajarkan di sekolah-sekolah dengan frekuensi jam pelajaran yang lebih banyak bila dibandingkan dengan mata pelajaran yang lain. Sudjana (Kompri, 2015: 228) mengatakan "hasil belajar merupakan prestasi belajar siswa secara keseluruhan yang menjadi indikator kompetensi dan derajat perubahan perilaku yang bersangkutan. Hasil belajar yang dicapai siswa dapat dipengaruhi oleh dua faktor utama yakni faktor internal dan faktor eksternal. Faktor internal merupakan faktor yang berasal dari dalam diri siswa sedangkan faktor eksternal merupakan faktor yang berasal dari luar diri siswa atau dari lingkungan. Clark (Kompri, 2015: 228) menyatakan bahwa "hasil belajar siswa di sekolah $70 \%$ dipengaruhi oleh kemampuan siswa dan 30\% dipengaruhi oleh lingkungan". Dari uraian tersebut sangat jelas bahwa antara faktor internal dan faktor eksternal saling berkaitan dan sangat dibutuhkan dalam belajar. Salah satu faktor eksternal yang dapat mempengaruhi hasil belajar adalah fasilitas, baik yang berada di sekolah maupun di rumah. Selain fasilitas, terdapat pula motivasi belajar yang merupakan salah satu faktor internal yang dapat mempengaruhi hasil belajar.

Dampak penyebaran COVID-19 membuat pembelajaran di Indonesia menjadi pembelajaran daring. Pembelajaran daring merupakan kegiatan belajar mengajar menggunakan jaringan internet. Dalam surat edaran Kemendikbud nomor 15 tahun 2020 dibahas mengenai pedoman pembelajaran jarak jauh (PJJ) dalam masa darurat penyebaran COVID-19. Dalam surat edaran tersebut disebutkan bahwa PJJ dibagi ke dalam dua pendekatan, salah satunya pembelajaran jarak jauh dalam jaringan (daring).

SMP Muhammadiyah Palangka Raya merupakan salah satu sekolah yang menerapkan pembelajaran daring. Adapun pembelajaran daring yang dilakukan menggunakan model pembelajaran Blanded Learning sehingga kegiatan inti pembelajaran dilakukan menggunakan beberapa media online seperti Zoom, Google Classroom, dan grup WhatsApp. Siswa-siswi di SMP Muhammadiyah Palangka Raya memiliki latar belakang yang berbeda-beda dari segi ekonomi dan penghasilan orang tua siswa, hal tersebut menentukan fasilitas di rumah yang dimiliki siswa juga beragam dan berbeda. Orang tua yang berpenghasilan tinggi kemungkinan lebih mudah dalam menyediakan fasilitas di rumah bagi siswa, guna menunjang proses belajar. Sebaliknya siswa yang berasal dari keluarga berpenghasilan lebih rendah maka dalam menyediakan fasilitas di rumah juga terbatas. Dengan kata lain, sebagian siswa di SMP Muhammadiyah Palangka Raya masih belum memiliki fasilitas di rumah yang memadai guna menunjang pembelajaran secara daring. Hal ini ditunjukkan dari sebagian siswa yang dapat dikatakan sering bahkan tidak pernah hadir dalam kegiatan belajar melalui Zoom. Menurut informasi guru mata pelajaran, alasan beberapa siswa yang tidak hadir dikarenakan siswa tersebut tidak memiliki handphone atau laptop pribadi yang terakses jaringan internet, sehingga mengharuskan siswa tersebut bergantian dalam menggunakan handphone dengan saudara ataupun orang tuanya. Bahkan pada saat pengumpulan tugas yang seharusnya dikumpulkan melalui media online Google Classroom atau WhatsApp, sebagian siswa justru mengumpulkan tugasnya ke sekolah. Sehingga penelitian ini bertujuan untuk mengetahui Diterminasi Hasil Belajar Matematika Siswa Kelas VIII SMP Muhammadiyah Palangka Raya jika ditinjau dari Fasilitas dan Motivasi Belajar.

Menurut Sudjana (Kompri, 20I5: 228) "hasil belajar adalah kemampuan-kemampuan yang dimiliki siswa setelah ia menerima pengalaman belajar". Sedangkan menurut Dimyati dan Mudjiono (2015: 200) "hasil belajar merupakan suatu tingkat keberhasilan yang dicapai oleh siswa setelah mengikuti kegiatan pembelajaran, tingkat keberhasilan tersebut kemudian ditandai dengan skala nilai berupa huruf atau kata atau simbol". Hasil belajar dalam pelajaran matematika merupakan suatu perubahan yang terjadi dalam diri siswa setelah melakukan proses belajar matematika sesuai dengan tujuan pembelajarannya. Hasil belajar itu sendiri meliputi tiga aspek yaitu kognitif, afektif, dan psikomotorik. Dalam proses pembelajaran matematika biasanya kemampuan yang diharapkan adalah pada aspek kognitif, karena berkaitan dengan kemampuan siswa untuk memahami pembelajaran matematika tersebut. Untuk mengetahui hasil belajar matematika siswa maka digunakan evaluasi belajar, yaitu kegiatan yang dilakukan secara kontinu dengan menggunakan alat evaluasi seperti tes, baik tes pilihan ganda maupun tes uraian. Dari hasil tes tersebut guru dapat melihat sejauh mana tujuan pembelajaran tersebut tercapai. Hasil belajar matematika yang dimaksud pada penelitian ini yaitu hasil belajar matematika dilihat pada aspek kognitif dengan alat evaluasi tes pilihan ganda pada materi teorema phytagoras dan lingkaran.

Fasilitas diartikan sebagai segala sesuatu yang dapat mempermudah dan melancarkan pelaksanaan suatu usaha. Alat-alat belajar adalah 
salah satu komponen fasilitas dalam membantu proses belajar siswa. Djamarah (2011: 184) menyatakan bahwa fasilitas belajar merupakan kelengkapan belajar yang harus dimiliki oleh sekolah. Kelengkapan belajar yang dimaksud meliputi sarana dan prasarana yang digunakan dalam proses pembelajaran baik di rumah maupun di sekolah. Fasilitas yang baik diharapkan dapat mendukung siswa memperoleh hasil belajar yang maksimal. Aunurrahman (2016: 195), menambahkan bahwa sarana dan prasarana pembelajaran merupakan faktor yang turut memberikan pengaruh terhadap hasil belajar siswa. Keadaan gedung sekolah dan ruang kelas yang tertata dengan baik, ruang perpustakaan sekolah yang teratur, tersedianya fasilitas kelas dan laboratorium, tersedianya buku-buku pelajaran, media atau alat bantu belajar merupakan komponen-komponen penting yang dapat mendukung terwujudnya kegiatan-kegiatan belajar siswa. Syah (2010: 154) menyatakan bahwa alat belajar merupakan faktor yang berpengaruh dalam menentukan tingkat keberhasilan belajar siswa. Fasilitas merupakan salah satu faktor yang mempengaruhi proses pembelajaran. Proses pembelajaran semakin produktif jika siswa, guru dan materi pelajaran didukung oleh fasilitas yang memadai serta pemanfaatan yang baik sehingga dapat menghasilkan hasil belajar yang maksimal.

Menurut Slameto (2018: 196) indikator fasilitas antara lain: I) ruang atau tempat belajar, sebuah syarat untuk dapat belajar dengan sebaikbaiknya adalah tersedia tempat belajar yang khusus. Setiap siswa hendaknya mengusahakan agar dapat menggunakan tempat belajar yang khusus. Tempat belajar di rumah yang nyaman yaitu cukup luas untuk aktifitas belajar, warna tembok yang menarik, dilengkapi ventilasi udara dan dilengkapi dengan penerangan yang cukup. 2) perabot belajar, benda-benda seperti perlengkapan belajar adalah benda-benda yang membantu tercapainya suatu proses belajar, yaitu: meja belajar khusus, kursi belajar khusus, lampu belajar, almari/rak buku dan rak sepatu. 3) alat bantu belajar. Alat dan benda sebagai perlengkapan bantu belajar adalah alat tulis yang lengkap, jangka, busur derajat, alat hitung kalkulator dan laptop atau komputer. Semakin lengkap alat-alat tentunya semakin dapat belajar dengan baik dan belajar tidak dapat dilakukan tanpa adanya alat-alat belajar secukupnya. 4) sumber belajar. Sebagai sumber belajar bagi siswa yaitu buku pelajaran, akses internet, radio, majalah atau koran, dan televisi. Internet dapat diakses dengan handphone, laptop atau komputer.

Motivasi berasal dari kata "motif", kata motif diartikan sebagai daya upaya yang mendorong seseorang untuk melakukan sesuatu. Motif dapat dikatakan sebagai daya penggerak dari dalam subjek untuk melakukan aktivitas-aktivitas tertentu demi mencapai suatu tujuan. Sehingga motivasi diartikan sebagai daya penggerak yang telah menjadi aktif. Motif menjadi aktif pada saat-saat tertentu, terutama bila kebutuhan untuk mencapai tujuan sangat dirasakan atau mendesak.

Mc. Donald (Kompri, 20I5: 229) menyatakan bahwa motivasi adalah suatu perubahan energi di dalam pribadi seseorang yang ditandai dengan timbulnya afektif (perasaan) dan reaksi untuk mencapai tujuan. Menurut Suryabrata (Kompri, 20I5: 3) menyatakan bahwa motif adalah keadaan dalam pribadi orang yang mendorong individu untuk melakukan aktivitas-aktivitas tertentu guna mencapai suatu tujuan. Soemanto (Majid, 20l4: 307) menyatakan bahwa motivasi sebagai suatu perubahan tenaga yang ditandai oleh dorongan efektif dan reaksi-reaksi pencapaian tujuan. Thontowi (Kompri, 20I5: 3) juga menyatakan bahwa tindakan belajar yang bermotif dapat dikatakan sebagai tindakan belajar yang dilakukan oleh anak didik yang didorong oleh kebutuhan yang dirasakannya, sehingga tindakan itu tertuju ke arah suatu tujuan yang diidamkan. Majid (2014: 308) menyatakan bahwa motivasi adalah energi aktif yang menyebabkan terjadinya suatu perubahan pada diri seseorang yang tampak pada gejala kejiwaan, perasaan, dan juga emosi sehingga mendorong individu untuk melakukan sesuatu dikarenakan adanya tujuan atau keinginan yang harus terpuaskan. Kompri (20I5: 3) menyatakan bahwa motivasi dapat diartikan sebagai kekuatan (energi) seseorang yang dapat menimbulkan tingkat persistensi dan antusismenya dalam melaksanakan suatu kegiatan, baik yang bersumber dari dalam diri individu itu sendiri maupun dari luar diri individu.

Sadirman (Majid, 2014: 309) memberikan tiga fungsi motivasi, yaitu: I) mendorong manusia untuk berbuat. Artinya motivasi bisa dijadikan sebagai penggerak atau motor yang melepaskan energi. Motivasi dalam hal ini merupakan motor penggerak dari setiap kegiatan yang akan dikerjakan, 2) menentukan arah perbuatan ke arah tujuan yang hendak dicapai. Dengan demikian, motivasi dapat memberikan arah dan kegiatan yang harus dikerjakan sesuai dengan rumusan tujuannya, dan 3) menyeleksi perbuatan, yakni menentukan perbuatan-perbuatan apa yang harus dikerjakan yang serasi guna mencapai tujuan, dengan menyisih perbuatan-perbuatan yang tidak bermanfaat bagi tujuan tersebut.

Penelitian tentang fasilitas dan hasil belajar telah dilakukan oleh Ery (2013) yang menyimpulkan bahwa ada hubungan yang positif dan signifikan antara fasilitas belajar di rumah dengan hasil belajar matematika siswa dengan nilai $r$ sebesar 0,4292 
pada taraf signifikan 5\%. Penelitian lain juga dilakukan oleh Pancarita dan Haryani (2020) yang menyatakan bahwa terdapat hubungan positif yang signifikan antara pemanfaatan fasilitas belajar dengan hasil belajar matematika, koefisien korelasinya sebesar $r_{\text {hitung }}=0,58$. Penelitian tentang motivasi belajar dan hasil belajar telah dilakukan oleh Jatmiko (2015) yang menyatakan bahwa terdapat hubungan positif yang signifikan motivasi belajar dengan hasil belajar matematika, koefisien korelasinya sebesar $r_{\text {hitung }}=0,32$.

Penelitian lain juga dilakukan oleh Armida (2015) yang menyimpulkan bahwa terdapat hubungan positif yang signifikan antara motivasi belajar dengan hasil belajar matematika koefisien korelasinya $(r)=0,91, t_{0,05}=27,87$.

\section{Metode Penelitian}

Populasi dalam penelitian ini adalah seluruh siswa Kelas VIII SMP Muhammadiyah Palangka Raya tahun ajaran 202I/2022 yang terdiri dari 5 kelas sebanyak I6I siswa. Ukuran sampel dalam penelitian ini adalah 119 siswa.

Untuk memperoleh data fasilitas dan motivasi belajar digunakan angket dengan model skala Likert sedangkan data hasil belajar matematika siswa digunakan tes. Pengumpulan data dilakukan secara online, dengan menggunakan media Google Formulir. Adapun langkah-langkah pengumpulan data sebagai berikut: I) menyiapkan angket fasilitas, angket motivasi belajar dan tes hasil belajar matematika untuk diisi siswa secara online menggunakan Google Formulir, 2) menginformasikan kepada guru matematika mengenai waktu penyebaran angket, agar guru matematika menginformasikan kepada siswa melalui grup WhatsApp setiap kelas, 3) menyebarkan angket yang telah diuji coba secara online, dengan cara mengirimkan link Google Formulir yang berisi butirbutir pernyataan angket fasilitas dan motivasi belajar ke grup WhatsApp setiap kelas, 4) mengumpulkan data angket yang telah diisi oleh siswa untuk dihitung skor masing-masing siswa, 5) menginformasikan kepada guru matematika mengenai waktu pengadaan tes hasil belajar matematika, agar guru matematika menginformasikan kepada siswa melalui grup WhatsApp setiap kelas, 6) mengadakan tes hasil belajar matematika secara online, dengan cara mengirimkan link Google Formulir yang berisi butirbutir pertanyaan soal tes matematika ke grup WhatsApp setiap kelas, 7) mengumpulkan data tes hasil belajar yang telah dikerjakan siswa untuk dihitung nilai masing-masing siswa, 8) mengolah data, dan 9) menyusun Laporan.
Agar mendapatkan instrumen yang baik dan valid dalam mengungkapkan data penelitian maka instrumen penelitian tersebut disusun dengan langkah- langkah sebagai berikut: I) menyusun kisikisi instrumen penelitian berupa angket fasilitas dan motivasi belajar serta tes hasil belajar matematika yang di dalamnya menguraikan masing-masing variabel menjadi beberapa indikator, 2) berdasarkan kisi-kisi, selanjutnya menyusun butirbutir pernyataan angket dan soal tes hasil belajar matematika, 3) mengadakan uji coba instrumen yang telah disusun. Uji coba instrumen ini dilakukan pada siswa yang tidak dikenakan sebagai sampel, 4) menganalisis hasil uji coba instrumen untuk mengetahui validitas dan reliabilitas instrument, 5) berdasarkan hasil analisis uji coba instrumen ditentukan instrumen yang valid dan reliabel untuk digunakan dalam pengambilan data masing-masing variabel. Adapun indikator angket fasilitas meliputi: ketersediaan dan keadaan ruang belajar di rumah, ketersediaan perabot belajar di rumah, ketersediaan dan pemanfaatan alat bantu dalam pembelajaran daring, dan ketersediaan dan pemanfaatan media atau sumber selama pembelajaran daring. Sedangkan indikator angket motivasi belajar meliputi: adanya kebutuhan, adanya pengetahuan tentang kemajuan diri sendiri, adanya aspirasi atau cita-cita, kegigihan dalam belajar, ganjaran, pesaing/kompetisi. Adapun indikator tes hasil belajar matematika meliputi: memahami rumus dari teorema pythagoras, menentukan panjang sisi segitiga siku-siku jika panjang dua sisi diketahui, menuliskan tiga bilangan ukuran panjang sisi segitiga siku-siku (tripel pythagoras), menggunakan hasil pembelajaran torema pythagoras dan tripel pythagoras pada bangun datar, menyelesaikan masalah yang berkaitan dengan penerapan teorema pythagoras dan triple pythagoras, mengenal lingkaran, menentukan hubungan antara sudut pusat dengan sudut kelilling, menentukan panjang busur dan luas juring, menyelesaikan masalah yang berkaitan dengan sudut pusat, sudut keliling, panjang busur, dan luas juring lingkaran serta hubungannya, dan menghitung garis singgung lingkaran.

Untuk menguji validitas instrumen berupa angket digunakan rumus korelasi Product Moment (Sugiyono, 2015: 228). Untuk menguji validitas instrumen yang berupa tes, digunakan Indeks Kesukaran (IK) dan Daya Pembeda (D) (Arikunto, 2013: 224). Untuk memperoleh reliabilitas instrumen berupa angket, digunakan rumus Alpha (Arikunto, 2013: 239). Untuk memperoleh reliabilitas instrumen tes digunakan rumus KR-20 (Arikunto, 2013: 230).

Analisis data menggunakan Korelasi Product Moment (Sugiyono, 2015: 255) dan 
Korelasi Ganda. Selanjutnya ditentukan nilai Diterminasi dari korelasi ganda tersebut dengan cara mengkuadratkan (R). Namun sebelum data dianalisis diuji dulu normalitasnya dengan rumus Chi kuadrat $\left(\chi^{2}\right)$.

Hasil Penelitian dan Pembahasan
Berdasarkan hasil penelitian data fasilitas didapat rentang skor 63 sampai 130. Data di kelompokkan dalam 8 kelas interval dengan panjang kelas setiap intervalnya adalah 9. Rata-rata skor fasilitas sebesar 98,09 dan simpangan baku sebesar 14,70. Distribusi frekuensinya dapat dilihat pada tabel berikut:

Tabel I. Distribusi Frekuensi Data Skor Fasilitas

\begin{tabular}{|c|c|c|c|c|c|c|}
\hline Kelas & Interval & $\begin{array}{c}\text { Nilai } \\
\text { tengah }\end{array}$ & Frekuensi & $\begin{array}{c}\text { Frekuensi } \\
\text { Komulatif }\end{array}$ & $\begin{array}{c}\text { Frekuensi } \\
\text { Relatif }\end{array}$ & $\begin{array}{c}\text { Frekuensi Relatif } \\
\text { Komulatif }\end{array}$ \\
\hline 1 & $63-71$ & 67 & 6 & 6 & 5.042 & 5.042 \\
\hline 2 & $72-80$ & 76 & 10 & 16 & 8.403 & 13.445 \\
\hline 3 & $81-89$ & 85 & 19 & 35 & 15.966 & 29.412 \\
\hline 4 & $90-98$ & 94 & 29 & 64 & 24.370 & 53.782 \\
\hline 5 & $99-107$ & 103 & 23 & 87 & 19.328 & 73.109 \\
\hline 6 & $108-116$ & 112 & 17 & 104 & 14.286 & 87.395 \\
\hline 7 & $117-125$ & 121 & 13 & 117 & 10.924 & 98.319 \\
\hline 8 & $126-134$ & 130 & 2 & 119 & 1.681 & 100 \\
\hline \multicolumn{2}{|r|}{ Jumlah } & & 119 & & 100 & \\
\hline
\end{tabular}

Dari tabel di atas bahwa skor rata-rata 98,09 berada pada interval 90 sampai 98 yaitu sebanyak 29 siswa (24,37\%), siswa yang memperoleh skor di bawah kelas interval rata-rata sebanyak 35 siswa (29,4l\%), dan siswa yang memperoleh skor di atas kelas interval rata-rata sebanyak 55 siswa (46,22\%).

Berdasarkan hasil penelitian data motivasi belajar didapat rentang skor adalah 62 sampai 140. Data di kelompokkan dalam 8 kelas interval dengan panjang kelas setiap intervalnya adalah 10. Rata-rata skor motivasi belajar sebesar 108,5I dan simpangan baku sebesar II7,10. Dsitribusi frekuensi data skor motivasi belajar dapat dilihat pada tabel 2 berikut:

Tabel 2. Distribusi Frekuensi Data Skor Motivasi Belajar

\begin{tabular}{|c|c|c|c|c|c|c|}
\hline Kelas & Interval & $\begin{array}{c}\text { Nilai } \\
\text { Tengah }\end{array}$ & Frekuensi & $\begin{array}{l}\text { Frekuensi } \\
\text { Komulatif }\end{array}$ & $\begin{array}{c}\text { Frekuensi } \\
\text { Relatif }\end{array}$ & $\begin{array}{c}\text { Frekuensi Relatif } \\
\text { Komulatif }\end{array}$ \\
\hline I & $62-71$ & 66.5 & 1 & 1 & 0.840 & 0.840 \\
\hline 2 & $72-8 I$ & 76.5 & 8 & 9 & 6.723 & 7.563 \\
\hline 3 & $82-91$ & 86.5 & 11 & 20 & 9.244 & 16.807 \\
\hline 4 & $92-101$ & 96.5 & 20 & 40 & 16.807 & 33.613 \\
\hline 5 & $102-111$ & 106.5 & 24 & 64 & 20.168 & 53.782 \\
\hline 6 & 1.2121 & 116.5 & 31 & 95 & 26.050 & 79.832 \\
\hline 7 & $|22-13|$ & 126.5 & 15 & 110 & 12.605 & 92.437 \\
\hline 8 & $|32-| 4 \mid$ & 136.5 & 9 & 119 & 7.563 & 100 \\
\hline \multicolumn{2}{|c|}{ Junlah } & & 119 & & 100 & \\
\hline
\end{tabular}

Dari tabel di atas bahwa skor rata-rata 108,5 I berada pada interval 102 sampai III yaitu sebanyak 24 siswa (20,17\%), siswa yang memperoleh skor di bawah kelas interval rata-rata sebanyak 40 siswa (33,6I\%), dan siswa yang memperoleh skor di atas kelas interval rata-rata sebanyak 55 siswa (46,22\%).

Berdasarkan hasil penelitian data hasil belajar matematika di dapat rentang nilai adalah 27 sampai 97. Data di kelompokkan dalam 8 kelas interval dengan panjang kelas setiap intervalnya adalah 9. Rata-rata nilai hasil belajar matematika sebesar 64,57 dan simpangan baku sebesar 16,33. Distribusi frekuensi data hasil belajar matematika dapat dilihat pada tabel 3 berikut:

Tabel 3. Distribusi Frekuensi Data Nilai Hasil Belajar Matematika 
Sugiharto', Karlinah Salamanya ${ }^{2,}$ Walter Punding ${ }^{3}$ dan Yupito $^{4 *}$.Determinasi Hasil Belajar Matematika ditinjau dari Fasilitas dan Motivasi Belajar Siswa Kelas VIII SMP Muhammadiyah Palangka Raya.

\begin{tabular}{|c|c|c|c|c|c|c|}
\hline Kelas & Interval & $\begin{array}{c}\text { Nilai } \\
\text { Tengah }\end{array}$ & Frekuensi & $\begin{array}{l}\text { Frekuensi } \\
\text { Komulatif }\end{array}$ & $\begin{array}{c}\text { Frekuensi } \\
\text { Relatif }\end{array}$ & $\begin{array}{c}\text { Frekuensi Relatif } \\
\text { Komulatif }\end{array}$ \\
\hline I & $27-35$ & 31 & 6 & 6 & 5.042 & 5.042 \\
\hline 2 & $36-44$ & 40 & 11 & 17 & 9.244 & 14.286 \\
\hline 3 & $45-53$ & 49 & 12 & 29 & 10.084 & 24.370 \\
\hline 4 & $54-62$ & 58 & 18 & 47 & 15.126 & 39.496 \\
\hline 5 & $63-71$ & 67 & 30 & 77 & 25.210 & 64.706 \\
\hline 6 & $72-80$ & 76 & 23 & 100 & 19.328 & 84.034 \\
\hline 7 & $81-89$ & 85 & 13 & 113 & 10.924 & 94.958 \\
\hline 8 & $90-98$ & 94 & 6 & 119 & 5.042 & 100 \\
\hline \multicolumn{2}{|c|}{ Jumlah } & & 119 & & 100 & \\
\hline
\end{tabular}

Dari tabel di atas bahwa nilai rata-rata 64,57 berada pada interval 63 sampai 7l yaitu sebanyak 30 siswa $(25,21 \%)$, siswa yang memperoleh nilai di bawah kelas interval rata-rata sebanyak 47 siswa (39,50\%), dan siswa yang memperoleh nilai di atas kelas interval rata-rata sebanyak 42 siswa $(35,29 \%)$.

Uji prasyarat analisis yang digunakan adalah uji normalitas dengan uji Chi-Kuadrat. Berdasarkan perhitungan uji normalitas data skor fasilitas diperoleh $\chi^{2}$ hitung sebesar 4,40 dengan harga $\chi_{\text {tabel }}^{2}$ dengan $\mathrm{dk}=5$ dan $\alpha=0,05$ adalah sebesar I I,07 maka $\chi_{\text {hitung }}^{2} \leq \chi_{\text {tabel }}^{2}$ (berdistribusi normal).
Uji normalitas data skor motivasi belajar diperoleh $\chi^{2}$ hitung sebesar 4,76 dengan harga $\chi^{2}{ }_{\text {tabel }}$ dengan $d k$ $=5$ dan $\alpha=0,05$ adalah sebesar 1 I,07 maka $\chi^{2}$ hitung $\leq \chi_{\text {tabel }}^{2}$ (berdistribusi normal). Uji normalitas data nilai hasil belajar matematika diperoleh $\chi^{2}$ hitung sebesar 5,46 dengan harga $\chi_{\text {tabel }}^{2}$ dengan $d k=5$ dan $\alpha=0,05$ adalah II,07 sebesar maka $\chi_{\text {hitung }}^{2} \leq \chi_{\text {tabel }}^{2}$ (berdistribusi normal). Data hasil perhitungan uji normalitas dari ketiga variabel dapat dilihat pada tabel

berikut

Tabel 4. Hasil Analisis Uji Normalitas Data

\begin{tabular}{|c|c|c|c|c|}
\hline Variabel & $\chi^{2}$ hitung & $\chi^{2}$ tabel & $\begin{array}{c}\text { Kaidah } \\
\text { Keputusan }\end{array}$ & Keterangan \\
\hline Fasilitas $\left(X_{l}\right)$ & 4,40 & 11,07 & $X_{\mathrm{h}}^{2} \leq \chi_{\mathrm{t}}^{2}$ & $\begin{array}{c}\text { Berdistribusi } \\
\text { Normal }\end{array}$ \\
\hline $\begin{array}{c}\text { Motivasi Belajar } \\
\left(X_{2}\right)\end{array}$ & 4,76 & 11,07 & $\chi_{\mathrm{h}}^{2} \leq \chi_{\mathrm{t}}^{2}$ & $\begin{array}{l}\text { Berdistribusi } \\
\text { Normal }\end{array}$ \\
\hline $\begin{array}{c}\text { Hasil Belajar } \\
\text { Matematika (Y) }\end{array}$ & 5,46 & 11,07 & $\chi_{\mathrm{h}}^{2} \leq \chi_{\mathrm{t}}^{2}$ & $\begin{array}{l}\text { Berdistribusi } \\
\text { Normal }\end{array}$ \\
\hline
\end{tabular}

Hasil analisis data dengan menggunakan korelasi Product Moment, diperoleh koefisian korelasi fasilitas dengan hasil belajar matematika siswa sebesar 0,33. Sedangkan $r_{\text {tabel }}$ untuk $N=119$ sebesar 0,18, sehingga $r_{\left(x_{1} y\right)}>r_{t(0,05)}=0,33>$ 0, I8. Uji signifikansi menggunakan $t$, diperoleh nilai $t_{\text {hitung }}$ sebesar 3,78 . Nilai $t_{\text {tabel }}$ dengan $d k=119-2$ $=117$ dan $\alpha=5 \%$ adalah sebesar I,98. Nilai $t_{\text {hitung }}>$ $t_{\text {tabel, }}$ sehingga dapat dinyatakan bahwa $\mathrm{Ho}_{\mathrm{l}}$ ditolak dan $\mathrm{Ha}_{1}$ diterima. Sehingga dapat disimpulkan bahwa ada hubungan positif yang signifikan fasilitas dengan hasil belajar matematika.

Hasil analisis data dengan menggunakan korelasi Product Moment, diperoleh koefisian korelasi motivasi belajar dengan hasil belajar matematika siswa sebesar 0,43. Sedangkan $r_{\text {tabel }}$ untuk $N=119$ sebesar 0,18 , sehingga $r_{\left(x_{2} y\right)}>r_{t}$ $(0,05)=0,43>0,18$. Uji signifikansi menggunakan $t$, diperoleh nilai $t_{\text {hitung }}$ sebesar 5,15 . Nilai $t_{\text {tabel }}$ dengan $d k=119-2=117$ dan $\alpha=5 \%$ adalah sebesar 1,98 . Nilai $t_{\text {hitung }}>t_{\text {tabel}}$, dapat dinyatakan bahwa $\mathrm{Ho}_{1}$ ditolak dan $\mathrm{Ha}_{l}$ diterima. Sehingga dapat disimpulkan bahwa ada hubungan positif yang signifikan motivasi belajar dengan hasil belajar matematika.

Hasil analisis data dengan menggunakan korelasi ganda, diperoleh koefisien korelasi fasilitas dan motivasi belajar dengan hasil belajar matematika sebesar 0,77. Sedangkan $r_{\text {tabel }}$ untuk $N$ $=119$ sebesar 0,18 , sehingga $r_{\left(y x_{1} x_{2}\right)}>r_{t(0,05)}=$ $0,77>0,18$. Uji signifikansi menggunakan uji $F$, diperoleh nilai $F$ sebesar 13,185 . Nilai $F_{\text {tabel }}$ dengan 
$d k$ pembilang $=2$ dan $d k$ Penyebut $=119-2-1=$ II 6 dan $\alpha=5 \%$ adalah sebesar 3,07. Nilai $F_{\text {hitung }}>$ $F_{\text {tabel}}$, dapat dinyatakan bahwa $\mathrm{Ho}_{3}$ ditolak dan $\mathrm{Ha}_{3}$ diterima. Sehingga dapat disimpulkan bahwa ada hubungan positif yang signifikan fasilitas dan motivasi belajar dengan hasil belajar matematika. Koefisien determinasi dihitung dengan mengkuadratkan Koefisien Korelasi (R). Hasil analisis data dengan menggunakan korelasi ganda, diperoleh koefisien korelasi fasilitas dan motivasi belajar dengan hasil belajar matematika sebesar 0,43 . Sehingga koefisien determinasinya sebesar 0,18 .

Berdasarkan hasil penelitian dengan analisis statistik dapat diketahui bahwa terdapat hubungan positif yang signifikan fasilitas dan motivasi belajar dengan hasil belajar matematika siswa kelas VIII SMP Muhammadiyah Palangka Raya tahun ajaran 202I/2022, menunjukkan bahwa hipotesis pertama, hipotesis kedua dan hipotesis ketiga diterima.

Untuk hipotesis yang pertama bahwa ada hubungan positif yang signifikan fasilitas dengan hasil belajar matematika siswa. Hal ini ditunjukkan oleh nilai $r_{\left(x_{1} y\right)}$ sebesar 0,33 dengan $r_{\text {tabel }}=0,18$, dan untuk uji signifikan koefisien korelasi $t_{\text {hitung }}>t_{\text {tabel }}$ yaitu 3,78 > 1,98 dengan $d k=119-2=117$ pada taraf signifikan $5 \%$. Semakin memadai fasilitas yang dimiliki siswa dalam belajar maka hasil belajar matematika siswa akan semakin tinggi. Hal ini juga sejalan dengan penelitian yang dilakukan oleh Ery (20I3) yang menyatakan bahwa ada hubungan positif yang signifikan fasilitas dengan hasil belajar matematika siswa. Oleh karena itu, dapat disimpulkan bahwa ada hubungan fasilitas dengan hasil belajar matematika.

Untuk hipotesis yang kedua bahwa ada hubungan positif yang signifikan motivasi belajar dengan hasil belajar matematika siswa. Hal ini ditunjukkan oleh nilai $r_{\left(x_{2} y\right)}$ sebesar 0,43 dengan $r_{\text {tabel }}=0,18$, dan untuk uji signifikan koefisien korelasi $t_{\text {hitung }}>t_{\text {tabel }}$ yaitu $5,15>1,98$ dengan $d k=$ $119-2=117$ pada taraf signifikan $5 \%$. Semakin baik motivasi yang dimiliki siswa dalam belajar maka hasil belajar matematika siswa akan semakin tinggi. Hal ini juga sejalan dengan penelitian yang dilakukan oleh Armida (20I5) yang menyatakan bahwa ada hubungan positif yang signifikan motivasi belajar dengan hasil belajar matematika siswa. Sehingga, dapat disimpulkan ada hubungan motivasi belajar dengan hasil belajar matematika.

Untuk keofisien korelasi fasilitas dan motivasi belajar diperoleh sebesar 0,77 atau $r_{\mathrm{x}_{1} x_{\mathrm{z}}}$ $>r_{\mathrm{t}}(0,05)=0,77>0,18$, hal ini menunjukkan bahwa variabel fasilitas dan motivasi belajar beririsan atau ada persamaan.

Untuk hipotesis yang ketiga bahwa ada hubungan positif yang signifikan fasilitas dan motivasi belajar dengan hasil belajar matematika siswa yang ditunjukkan oleh $r_{y x_{1} x_{z}}$ nilai $r_{\left(x_{2} y\right)}$ sebesar 0,43 dengan $r_{\text {tabel }}=0,18$ dan untuk $F_{\text {hitung }}>$ $F_{\text {tabel }}$ yaitu sebesar $13,185>3,07$ dengan $d k$ pembilang $=2$ dan $\mathrm{dk}$ penyebut $=119-2-1=$ II 6 pada taraf signifikan 5\%. Adanya fasilitas yang memadai dan motivasi belajar siswa yang baik maka hasil belajar matematika siswa tersebut akan meningkat. Maupun sebaliknya, jika fasilitas siswa kurang memadai dan motivasi belajar siswa kurang baik pula maka hasil belajar matematika siswa tersebut akan kurang baik. Berdasarkan uraian di atas dapat disimpulkan bahwa semakin memadai fasilitas yang dimiliki siswa dan semakin baik motivasi belajar terhadap mata pelajaran matematika maka akan semakin baik pula hasil belajar matematika siswa tersebut.

Hasil analisis data dengan menggunakan korelasi ganda, diperoleh koefisien korelasi fasilitas dan motivasi belajar dengan hasil belajar matematika sebesar 0,43. Sehingga koefisien determinasinya sebesar 0,18. Berarti kemampuan fasilitas dan motivasi belajar dalam menjelaskan varians dari hasil belajar matematika sebesar $18,0 \%$. Berarti terdapat $82 \%$ (100\%-18\%) varians hasil belajar matematika dijelaskan oleh faktor lain.

\section{Kesimpulan} berikut:

Hasil penelitian dapat disimpulkan sebagai

I. Ada hubungan positif yang signifikan fasilitas dengan hasil belajar matematika siswa, dengan nilai $r_{\text {hitung }}$ sebesar 0,33 .

2. Ada hubungan positif yang signifikan motivasi belajar dengan hasil belajar matematika siswa, dengan nilai $r_{\text {hitung }}$ sebesar 0,43 .

3. Ada hubungan positif yang signifikan fasilitas dan motivasi belajar dengan hasil belajar matematika siswa, dengan nilai $R$ sebesar 0,43 .

4. Koefisien determinasi sebesar 0,18.

\section{Daftar Pustaka}

Arikunto. 2013. Prosedur Penelitian: Suatu Pendekatan Praktik. Jakarta: Rineka Cipta

Armida. 20I5. Hubungan antara Minat dan Motivasi Belajar dengan Hasil Belajar Matematika Siswa Kelas VII SMP Negeri 3 Palangka Raya. Skripsi Sarjana, tidak diterbitkan. Universitas Palangka Raya.

Aunurrahman. 2016. Belajar dan Pembelajaran. Bandung: Alfabeta. 
Dimyati \& Mudjiono. 20I5. Belajar dan Pembelajaran. Jakarta: Rineka Cipta.

Djamarah, S. B. 20II. Psikologi Belajar. Jakarta: Rineka Cipta.

Ery. 2013 Hubungan Antara Fasilitas Belajar dan Kemandirian Belajar Matematika dengan Hasil Belajar Matematika Siswa Kelas VIII Semester I Sedayu Kabupaten Bantul. Skripsi Sarjana, tidak diterbitkan, Universitas Ahmad Dahlan. Diunduh pada tanggal 19 Desember 2020 dari http://www.academia.edu

Jatmiko. 20I5. Hubungan Motivasi Belajar dengan Hasil Belajar Matematika Siswa Kelas X SMK Nahdhatul Ulama Pace Nganjuk. Jurnal Math Educator Nusantara, I(2): 205.

Kompri. 20I5. Motivasi Pembelajaran Prespektif Guru dan Siswa. Bandung: PT. REMAJA ROSDAKARYA.
Mairing, J.P. 2018. Pemecahan Masalah Matematika. Bandung: ALFABETA.

Majid, A. 2014. Strategi Pembelajaran. Bandung: PT. Remaja Rosdakarya

Pancarita \& Haryani, D. 2020. Hubungan Pemanfaatan Fasilitas Belajar dan Kemandirian Belajar dengan Hasil Belajar Matematika Siswa Kelas VIII MTS An Nur Palangka Raya. Jurnal Pendidikan, 2 I (2): II8.

Slameto. 2018. Belajar dan Faktor-Faktor yang Mempengaruhi. Jakarta: Rineka Cipta.

Sugiyono. 2015. Metode Penelitian Kuantitatif, Kualitatif dan R\&D. Bandung: Alfabeta

Syah, M. 2010. Psikologi Belajar. Jakarta: PT. Raja Grafindo Persada. 